Kadir Yağız $\mathbf{1}^{\mathbb{D}}$

\title{
Interactions among brand credibility, brand affect and brand behavioural intentions in professional sports teams: the moderation role of brand affect and live stadium attendance
}

\author{
${ }^{1}$ Republic of Turkey Ministry of National Education
}

\begin{abstract}
The purpose of this study was to investigate the effect of brand credibility and brand affect on behavioural intentions of professional sports team consumers toward their teams, and also investigating the moderating role of their brand affect level, live attendance frequency in stadium and gender on this relationship. Results showed that brand credibility and brand affect had a significant and positive effect on behavioural intentions. Also, the importance sports consumers attached to brand credibility of a team in respect to their behavioural intentions differed at their varying level of brand affect, live attendance frequency and gender. Through this study it was presented to sports managers about the mechanisms through which brand credibility exerts its effect on consumers' behavioural intentions across the varying level of brand affect, live attendance frequency and gender which would guide in their strategic brand management implementations.
\end{abstract}

Keywords: brand credibility, brand affect, brand behavioural intentions, sports teams, sports consumers

\section{Introduction}

Previous brand management studies in sports team context well established the relationship between brand loyalty and the drivers of the customer-based brand equity (CBBE) such as brand awareness and brand associations from the cognitive psychology perspective. Although the consumers' awareness of the brand and its perceived position within the product category through brand associations are essential on brand loyalty, sports marketers should not be limited to control only these structures in guiding the team loyalty of their consumers. Other crucial components of the CBBE such as cognitive and emotional consumer responses should also be managed carefully. For example, brand credibility is proposed one of the significant cognitive consumer responses which can have a direct effect on brand resonance that refers to the ultimate relationship between the brand and consumers (Keller, 2001), but has ignored in previous sports team branding literature. In addition, brand credibility is viewed in brand signalling theory as the primary determinant of CBBE and proposed to lead possible purchase intentions and formation of loyalty by increasing perceived quality, consumer utility and decreasing perceived risk (Erdem \& Swait, 1998).

The image of a brand, provided brand associations, are critical in terms of brand loyalty, however, this image should be perceived by consumers truthful and the

\footnotetext{
${ }^{1}$ Kadir Yağız, e-mail: kadiryagiz@ hacettepe.edu.tr, ORCID: 0000-0002-6465-9678
} 
organization must be able to deliver its promises credibly (Erdem et al., 2002). Thus, brand credibility can play a significant role in sports team consumers' behavioural intentions toward their team. Brand feelings are emotional consumer response which is also proposed to leads consumers to brand resonance (Keller, 2001). The brand feelings had little attention in the sports team branding literature, however, it was demonstrated in the sports service setting that brand affect had a significant positive effect on brand resonance as well as it was a full mediator on the relationship between brand resonance and brand superiority (Gordon \& James, 2017). The fact that brand superiority, as a cognitive brand response, did not have a direct effect on brand resonance in the sports service setting (e.g., Gordon \& James, 2017) contradicted the Keller's (2001) CBBE pyramid.

Based on the literature, so far, we know that brand affect had a direct effect on consumer attitudinal and behavioural intentions (brand resonance) and that there is a tremendous emotional bond between sports teams and their fans and that a sporting event experience is a purely emotional consumption (Mullin et al., 2007). Hence, brand emotion is a crucial consumer response to be considered in sports settings. On the other hand, we do not know if brand credibility has a direct effect on consumers' behavioural intentions as suggested by Keller (2001), and if it does, whether brand affect has an intervening role in this relationship in the context of sports teams. There are currently ambiguous results in the sports brand management literature about that the cognitive responses of consumers to sports brands will lead to direct positive behavioural outcomes for the brand. Therefore, more related studies necessary to provide clearer guidance about and further explain the nature of the relationship between consumer cognitive responses and behavioural outcomes toward a brand in the context of sports teams. Another unknown is whether the effect of brand credibility on behavioural intentions varies depending on the level of the brand affect of sports consumers, the attendance frequency of their team's matches in the stadium and their gender. Knowing consumer characteristics and consumption behaviours are an important consideration for the effectiveness of promotional strategies and tactics aimed to lead fan loyalty (Fink et al., 2002).

Thus, one of the objectives of this study is to investigate the effect of brand credibility judgement of sports team consumers on their behavioural intentions toward the team brand they supported. The second objective is to investigate the moderating role of brand affect level, live attendance frequency and gender of consumers on this relationship. Through this study, we attempt to clarify the otherwise ambiguous pattern of results about the nature of the relationship among consumer cognitive and emotional responses and behavioural intentions in sports brand management literature. By revealing the interaction effect of brand credibility with brand affect, live attendance frequency and gender of consumers on behavioural intentions, we extend and contribute to the body of knowledge in sports team branding literature beyond brand associations brand loyalty relationships. In addition, we present to managers of sports teams about the mechanisms through which brand credibility exerts its effect on consumers' behavioural intentions across the varying level of brand affect, live attendance frequency and gender which would guide in their strategic brand management implementations.

\section{Conceptual background and development of hypotheses}

The conceptual framework of this study is based on the CBBE pyramid (Keller, 2001) and brand signalling theory in the information economics (Erdem \& Swait, 1998). The CBBE pyramid involves four sequential steps to establish a lasting relationship with customers, 
called brand awareness, brand associations, brand responses and brand resonance. It is proposed in the model that customers who aware and have positive associations toward a brand will likely to engage an intense and active relationship (resonance) with that brand through positive responses. Brand judgements and brand feelings are two distinct response of consumers to the brand's marketing activities and sources of information about the brand. Brand judgments are cognitive evaluations of consumers related to the perceived quality, brand consideration, brand superiority and brand credibility of a brand comparing to the other brands. On the other hand, brand feelings reflect the emotional reactions of consumers toward a brand. According to Keller (2001), brand responses can affect consumer attitudinal and behavioural intentions and loyalty if consumer internalize and think positively about the brand, and therefore the success of marketing efforts depends on how consumers respond the brand. It is customer brand loyalty that allows an organization gaining competitive advantage (Aaker, 1991) such as charging a premium price, increase in market share (Chaudhuri \& Holbrook, 2001) and brand extension (Keller, 1993). Therefore, achieving brand loyalty, which was measured with respect to only behavioural intentions in this study is a key factor in the financial success of professional sports teams.

The research stream that followed the cognitive psychology perspective from Keller's (1993) concepts focused mostly on the first and second step of the CBBE pyramid, brand awareness and brand associations, which were viewed as fundamental drivers of sports consumers' loyal behaviours. The effect of brand associations well supported on fan loyalty (Gladden \& Funk, 2001; Bauer et al.; Filo et al., 2008; Doyle et al.,2013), behavioural intentions (Biscaia et al., 2013), affective attitude (Bauer et al., 2008), psychological commitment (Kunkel et al., 2014) and fan identification (Yağız, 2020) in the sports team and league context. Brand responses, the third stage of the CBBE pyramid, have been given little focus although the direct effect they have on consumers' behavioural intentions and the essential role they have between brand associations and behavioural intentions have been emphasized strongly (Keller, 2001). While brand awareness and brand associations play an essential role in attracting new customers (Keller, 2001), it becomes crucial for existing customers to continue to think favourably about the organization and to further the relationship (Sweney \& Swait, 2008). In this case, the development of brand responses must be considered. In the literature, perceived quality, which is one of the cognitive judgement of consumers (Keller, 2001) was positively associated and tested with consumer satisfaction, loyalty and behavioural intentions widely in general and sports markets (e.g., Parasuraman et al., 1988; Clemes et al., 2011; Cronin et al., 2000; Theodorakis \& Alexandris, 2008). A recent study (e.g., Gordon \& James, 2017), examined the effects of brand superiority and brand affect responses of sports team consumers on brand resonance, which comprises brand loyalty, sense of community and active engagement (e.g., Keller, 2001). According to the results of this study, brand affect had a significant and positive direct effect on brand resonance, however, brand superiority had a significant and positive indirect effect via brand affect. Latter result, was inconsistent with both CBBE pyramid and the above-mentioned studies on perceived quality which was represented as a cognitive judgement of consumers. Keller (2001), asserts that both appropriate cognitive appraisals and emotional reactions are required from customers for reaching the brand resonance. Hence, results in sports settings have indicated ambiguous conclusions about the positive direct effect of cognitive responses on behavioural intentions as proposed in CBBE pyramid. On the other hand, previous research has completely ignored the potential role that brand credibility can play in behavioural intentions of the sports team consumers, which this represents a 
considerable gap in the sports brand management literature. Hence, one of the objectives and contributions of this study is to account for this shortage and clarifying the ambiguous relationship between cognitive responses and behavioural intentions in previous sports team researches by considering brand credibility.

\section{Brand credibility}

From the information economics perspective, the asymmetric (firms know better than consumers about the product) and imperfect (consumers cannot easily evaluate the quality of the product) nature of the markets are taken into account, and the significance of credibility of a brand is highlighted (Erdem \& Swait, 1998). The crucial role of brand credibility mostly arises due to the uncertainty, resulted from the asymmetric and imperfect market condition (Erdem et al., 2002). Therefore, according to the brand signalling theory, brands are considered as a credible market signal by which organizations convey information about its product attributes and position to the consumers (Erdem \& Swait, 1998). Thus, brand credibility defined as "the believability of the product information contained in a brand, which requires that consumers perceive that the brand has the ability (i.e., expertise) and willingness (i.e., trustworthiness) to continuously deliver what has been promised" (Erdem \& Swait 2004, p. 192) and trustworthiness and expertise posited its two main components. Similarly, Keller (2001) stated that for a brand to be credible, it should be seen competent and innovative (perceived expertise), dependable and sensitive (trustworthiness) and fun and interesting (likability) by consumers.

The role of brand credibility has been well documented in the literature in products and services that require different levels of consumer involvement or uncertainty. It has been found that brand credibility increased perceived quality, decreased information cost and risk perceived by consumers in the product of juice and jeans (Erdem \& Swait, 1998); decreased effect of price sensitivity on consumer utility in multiple product categories (Erdem et al., 2002); the increased probability of brand consideration and brand choice in multiple product categories (Erdem \& Swait, 2004); enhances word-of-mouth, reduces switching behaviours via satisfaction, loyalty commitment and continuous commitment in the retail bank and long-distance telephone services (Sweney \& Swait, 2008); have an effect on brand loyalty in mobile phone users (Zayerkabeh et al., 2012); brand purchase intention in the automobile industry (Wang \& Yang, 2010), and brand-self and brand-social connection in higher education brands (An et al., 2019).

While the previous studies have been shown the significant effect of brand credibility on the attitudes and behaviours of consumers, the role of brand credibility on behavioural intentions of sports team consumers is still questionable. One of the reasons for the lack of research or attention on the role of brand credibility on sports team consumers' brand behaviours may be the idea that fans are in a highly informed and committed relationship with their teams and therefore do not face or feel any uncertainty or risk during the purchasing process. Consumers, attending live games in the stadium, watching a sporting event from media or supporting a sports team are not homogeneous. There can also be found many causal consumers besides fans in a sporting event. Fans are more passionate than casual followers, irrationals in their consuming behaviours, their purchasing seldom commercial and do not have a real choice (Nufer \& Rennhak, 2006) and they continuous to support their team whether it wins or loses (Mason, 1999). But a sporting event or team product (i.e., game) may be seen for new attracted ones or causal consumers as a higher customer-involvement product or risky, which may create an uncertainty in their decisions. Moreover, casual consumers may have a choice between 
alternative products (Nufer \& Rennhak, 2006), and they tend to cease to support when the team they support lose (Mason, 1999). Erdem and Swait (2004) found that brand credibility had a significant effect on consumer choices even in categories that are moderate levels of uncertainty, and the importance of credibility was stronger for individuals who perceive higher uncertainty when choosing in a given product category. Erdem and Swait (1998) also stated that consumer uncertainty might exist even after active information gathering or consumption. In terms of attending a sporting event, there might be risks such as violence, satisfaction or uncertainties for different consumers that may affect their brand preferences.

Also, the importance of brand credibility for consumers does not just exist in uncertain situations. For example, consumers seek to engage with brands which reflect their identity (Mittal, 2006), hence, consumers connect cognitive and emotional tie mostly with credible brands to achieve their self-concept and social identity (An et al., 2019). As a result, whether they are casual consumers or fans, credibility of a team brand can be a key signal for sports consumers to build a relationship. Brand credibility can have an effect on sports consumers' behavioural intentions since their perception of the trustworthiness and expertise of a team is valuable information, they use to judge the quality of the team, its performance and whether to continue the relationship with it. Therefore, we hypothesize that:

H1: The brand credibility judgment of football team consumers has a significant and positive effect on their behavioural intentions toward the team.

\section{Brand affect}

Brand affect, defined as "a brand's potential to elicit a positive emotional response in the average consumer as a result of its use" (Chaudhuri \& Holbrook, 2001, p. 82), probably one of the most specific and crucial brand responses of sports consumers to a sports team, a star or any sports organization to achieve favourable brand intentions. It is known that sports teams produce a stronger emotional response from their fans when compared with any other business (Couvelaere \& Richelieau, 2005). Keller (2001) proposed that besides positive cognitive evaluations, consumers should have a favourable emotional response to build a relationship with a brand. In line with this suggestion, the differential power of this emotion has already been evidenced on decision making of consumers in different product and services (e.g., Chaudhuri \& Holbrook, 2001; Matzler et al., 2006; Thompson et al., 2006) as well as on attitudinal and behavioural intentions of sports teams consumers (Gordon \& James, 2017). Hence, based on the previous research following hypothesis was proposed:

$\mathrm{H} 2$ : The brand affect evaluation of football team consumers has a significant and positive effect on their behavioural intentions toward the team.

What is another unknown in sports branding literature is how cognitive and emotional brand responses, in the example of brand credibility and brand affect, interact in development behavioural intentions? That is, the moderation role of brand affect on the relationship between brand credibility and behavioural intentions lacks empirical evidence, which bases the second objective and contribution of this study. Guttman (1986) treated fanatics as emotionally dedicated sport consumers (as cited in Mahony et al., 2000, p. 15), and the higher involvement, motivation and fan satisfaction are strongly linked with high media use and live attendance in sports (Pritchard \& Funk, 2006). Therefore, we further argue that the effect of brand credibility on behavioural intentions is not uniform across all consumers. Consumers differ according to their emotions toward a team, their live attendance frequency and their gender. Consumer characteristics are 
substantial consideration for the effectiveness of promotional strategies and tactics aimed to lead fan loyalty (Fink et al., 2002). In general, we believe that consumers who have a higher emotional response to the team and more live attendance will utilize brand credibility less in terms of their behavioural intentions. Conversely, consumers who have a less emotional response to the team and have less live attendance will utilize brand credibility more because they may seek more cognitive signals in their behaviours towards the brand. We also believe that the moderation effect of brand affect and live attendance frequency on the relationship between brand credibility and behavioural intentions is moderated by consumer gender. Because previous research has found significant differences in cognitive processes and behaviours among consumers' gender. (Melynk et al., 2009). Hence, we hypotheses that:

H3: The brand affect evaluation of football team consumers moderates the relationship between brand credibility judgement and behavioural intentions. That is, the effect of brand credibility on behavioural intentions tends to be larger when the brand affect is low than when it is high.

H4: The moderation role of brand affect evaluation on the relationship between consumers' brand credibility judgments and behavioural intentions varies by gender.

H5: The live attendance frequency of football team consumers moderates the relationship between brand credibility judgements and behavioural intentions. That is, the effect of brand credibility on behavioural intentions tends to be larger when the live attendance frequency is low than when it is high.

H6: The moderation role of live attendance frequency on the relationship between consumers' brand credibility judgments and behavioural intentions varies by gender.

\section{Method}

\section{Sample and measurement instruments}

Participants of the study were 216 volunteer sports consumers in Ankara city, supporting a football (soccer) team in the Turkish Super Football League. The participants' average age was $\mathrm{M}=32,20 \mathrm{SD}=9,10$ and $77.3 \%$ of whom were men (167) and $22.7 \%$ were women (49). $35.6 \%$ (77) of the respondents were married, $64.4 \%$ (139) were single, $60.7 \%$ had a different level of education under university degree, and $30.7 \%$ had a university or master's degree. In the Turkish Super Football League, teams play a total of 34 matches in one season. The means of the participants' answer to the open-ended question, which measured the frequency of attending their team's matches live at the stadium in the previous season, was 5.02. The data was first collected using the convenience sample method from students of a university that supports any team in the Turkish Super Football League. Afterwards, the online questionnaires with a direct link were transmitted to the other supporters directed by the student participants with the snowball sampling method for four weeks. After 19 questionnaires without variability in responses were removed, 216 questionnaires were deemed valid for analysis. Brand credibility scale was adapted from Sweeney and Swait (2008), and Erdem and Swait (2004), whereas brand affect and behavioural intentions scales were adapted from Gordon and James (2017). In the first part of the questionnaire, there were questions about the demographic structure of the participants. In the second part, there were 15 question items in total regarding the participants' evaluation levels of the variables of brand credibility (6 items), brand affect (6 items) and behavioural intentions ( 3 items). The items were measured using a 5-point Likert scale ( 1 = strongly disagree; 5 = strongly agree $)$. 


\section{Data analysis}

The descriptive statistics, data screening and multiple regression analysis of the study were tested by using IBM SPSS 26, and confirmatory factor analysis (CFA) was conducted by using Amos 24 statistical program to test the structural validity of the constructs. To investigate whether the effect of brand credibility on brand loyalty would change in magnitude and direction as a function of brand affect, live attendance and gender, moderation analyses (conditional process analysis) were performed by using Process Macro v3.4 with 5000 bootstrap resamples and 95\% confidence intervals (Hayes, 2013). The conditional effects of brand affect and live attendance on the relationship between brand credibility and behavioural intentions were tested through Process Macro Model 1, whereas the conditional effect of gender on these relationships was tested through Process Macro Model 3. In moderation tests, the size or sign of the effect of an independent variable on a dependent variable specified to a different level or value of a third variable(s) (Hayes \& Rockwood, 2017). If the interaction term created by the independent and moderator variable together is significant, or the $95 \%$ confidence intervals do not contain zero, the moderation is confirmed. (Little et al., 2007).

\section{Results}

\section{Preliminary analyses}

First, the distribution of variables was examined and found that there were no the skewness and kurtosis values not less than -2 and greater than +2 (Kline, 2005), which indicated that the data were normally distributed. Regarding the CFA results, which were performed by the maximum likelihood estimation method, there were high covariances between the item AFFC2 and AFFC3 which are the items of brand affect. CRDB6 that is the item of brand credibility also had a value of over $\geq 2.58$ in the standardized residual covariance matrix. Therefore, the items AFFC2 (because of lower factor loading than AFFC3) and CRDB6 were removed from the model during a few iterative tests. Finally, $\chi 2 / \mathrm{df}=2.282(\chi 2=$ $141,494 ; \mathrm{df}=62)$ was $\leq 3.00($ Kline, 2005); SRMR $=.048$ was $\leq .05$ (Byrne, 2001); GFI $=.909, \mathrm{TLI}=.948, \mathrm{NFI}=.911$, and $\mathrm{CFI}=.958$ were $\geq .90($ Kline, 2005$) ; \mathrm{RMSEA}=.077$ was $\leq .08$ (Hair et al., 2006). The goodness-of-fit indices indicated a satisfactory fit to data. Therefore, the structural validity of the constructs was achieved. All items loadings were above $\geq, 50$ (Hair et al., 2006) and all regression coefficients were significant $(p<.05$ two-tailed). All constructs had the suggested cut-off value of $\geq .70$ (Nunnaly, 1978) for composite reliability (CR). Average variance extracted (AVE) values ranged from ,62 to ,66 which indicated convergence validity and the internal consistency of the constructs while all squared correlations between the constructs were lower than the AVE of the factors (e.g., Fornell \& Larcker, 1981). Thus, discriminant validity was supported. In Table 1, the descriptive statistics, correlations, CFA results, AVE scores and CR were given.

\section{Testing for moderations}

Model 1 in Table 2 shows the results of multiple regression analysis between brand credibility, brand affect and behavioural intentions. According to the model, brand credibility $(\beta=0.28, \mathrm{p}<0.01)$ and brand affect $(\beta=0.60, \mathrm{p}<0.01)$ had a significant and positive effect on behavioural intentions. Brand credibility and brand affect accounted for a significant amount of the variance in behavioural intentions $(\mathrm{R} 2=.637, \mathrm{~F}=189.529, \mathrm{p}$ $<.001)$. Based on these results, Hypothesis 1 and 2 was accepted. 
Hierarchical regression analyses were performed to determine the conditional (moderation) effect of brand affect and live attendance separately on the relationship between brand credibility and behavioural intentions, and the moderation role of gender on the conditional effects of brand affect and live attendance on the mentioned relationship (see Hayes, 2013 for moderated moderation). In Model 2, the interaction term (BCRD x $\mathrm{BAFF}$ ) that is the product of independent (brand credibility) and the moderator variables (brand affect) were added to the first model (i.e., Model 1 in Table 1).

Table 1: Descriptive Statistics, Correlations, Confirmatory Factor Analysis Results, Average Variance Extracted and Composite Reliability Scores.

\begin{tabular}{|c|c|c|c|c|c|c|c|c|c|c|}
\hline $\begin{array}{l}\text { Constructs } \\
\text { litems }\end{array}$ & M & SD & 1 & 2 & 3 & $\beta$ & SE & $Z$ score & $\begin{array}{l}\text { AVE } \\
(\geq .50)\end{array}$ & $\begin{array}{l}\text { CR } \\
(\geq .70)\end{array}$ \\
\hline $\begin{array}{l}\text { 1. Brand } \\
\text { credibility } \\
\text { CRDB1a } \\
\text { CRDB2 } \\
\text { CRDB3 } \\
\text { CRDB4 } \\
\text { CRDB5 }\end{array}$ & 3.14 & 1.05 & & & & $\begin{array}{l}.88^{\star \star *} \\
.89^{\star \star *} \\
.81^{* \star *} \\
.72^{\star \star *} \\
.76^{\star \star *}\end{array}$ & $\begin{array}{l}.054 \\
.058 \\
.059 \\
.061\end{array}$ & $\begin{array}{l}18.117 \\
15.258 \\
12.528 \\
13.652\end{array}$ & .66 & .91 \\
\hline $\begin{array}{l}\text { 2. Brand } \\
\text { affect } \\
\text { AFFC1a } \\
\text { AFFC3 } \\
\text { AFFC4 } \\
\text { AFFC5 } \\
\text { AFFC6 }\end{array}$ & 3.35 & 1.05 & $\begin{array}{l}.647 \\
.419\end{array}$ & & & $\begin{array}{l}.68^{\star \star \star} \\
.70^{\star \star *} \\
.85^{\star \star *} \\
.88^{\star \star *} \\
.78^{\star \star *}\end{array}$ & $\begin{array}{l}.118 \\
.123 \\
.120 \\
.116\end{array}$ & $\begin{array}{l}9.404 \\
11.196 \\
11.567 \\
10.414\end{array}$ & .61 & .89 \\
\hline $\begin{array}{l}\text { 3. Brand } \\
\text { loyalty } \\
\text { LOY1a } \\
\text { LOY2 } \\
\text { LOY3 }\end{array}$ & 3.40 & 1.06 & $\begin{array}{l}.661 \\
.437\end{array}$ & $\begin{array}{l}.772 \\
.596\end{array}$ & & $\begin{array}{l}.85^{\star \star *} \\
.75^{\star \star *} \\
.76^{\star \star *}\end{array}$ & $\begin{array}{l}.077 \\
.074\end{array}$ & $\begin{array}{l}12.387 \\
12.615\end{array}$ & .62 & .83 \\
\hline $\begin{array}{l}\text { 4.Live } \\
\text { attendance } \\
\text { frequency }\end{array}$ & 5.02 & 6.16 & $\begin{array}{l}.450 \\
.202\end{array}$ & $\begin{array}{l}.466 \\
.217\end{array}$ & $\begin{array}{l}.527 \\
.277\end{array}$ & & & & & \\
\hline
\end{tabular}

Note: M: mean; SD: standard deviation; 1, 2 and 3: correlations; $\beta$ : standardized regression weights; SE: standard error; AVE: average variance extracted; CR: composite reliability; a: factor loadings fixed to the value of 1.0 ; the italic values in correlations are squared correlations; ${ }^{* * *}: \mathrm{P}<.001$.

Before the regression analysis, all variables affecting the dependent variable were centralized. Gender, age, education levels were also entered as control variables. Results were presented under Model 2 in Table 2 . All predictor variables, included in the analysis, explained a significant $67 \%$ of the variance in behavioural intentions $(\mathrm{F}=69.15 ; \mathrm{p}<.001)$. The results showed that the interaction term had a negative and significant effect $(\beta=-$ $.09 ; \mathrm{p}<.05)$. The significance of the interaction term indicates that brand affect moderates the proposed relationship. The changes in $\mathrm{R} 2$ with the addition of the conditional effect of brand affect $(\mathrm{F}=5.42 ; \mathrm{p}<.05)$ were also statistically significant. In addition, the nature of 
the relationship between brand credibility and behavioural intentions was examined at (1) low, (2) moderate, and (3) high levels of brand affect which was presented in Table 3 and it illustrated via simple slopes in Figure 1. High and low values of brand affect were one standard deviation above and below the mean, and moderate values were the mean. Based on the direction and statistical significance of the relationships Hypothesis 3 was evaluated. Interaction slopes showed that the effect of brand credibility on behavioural intentions was at $\beta=.36 ; p<.001$ level when the brand affect is low, decreases to $\beta=.27$; $p<.001$ level at a moderate level, and decreases to the lowest level $\beta=.17 ; p<.01$ when it is high. This means that the higher the brand affect level the lesser the brand credibility effect on behavioural intentions. Hence, Hypothesis 3 was accepted.

Table 2: Hierarchical Regression Analyses for Moderations

\begin{tabular}{|c|c|c|c|c|c|}
\hline Models / Predictors & \multicolumn{5}{|c|}{ Dependent variable (Behavioural intentions) } \\
\hline Model 1 & $\mathbf{R}^{2}$ & B & SE & $\mathrm{t}$ & $95 \% \mathrm{Cl}$ \\
\hline $\begin{array}{l}\text { Constant } \\
\text { BCRD } \\
\text { BAFF }\end{array}$ & $.637^{\star * *}$ & $\begin{array}{l}.506 \\
.280^{\star \star \star} \\
.601^{\star \star \star}\end{array}$ & $\begin{array}{l}.156 \\
.054 \\
.055\end{array}$ & $\begin{array}{l}3.249 \\
5.155 \\
10.974 \\
\end{array}$ & $\begin{array}{l}.199 / .812 \\
.173 / .388 \\
.493 / .709\end{array}$ \\
\hline $\begin{array}{l}\text { Model } 2 \\
\text { Constant } \\
\text { BCRD } \\
\text { BAFF } \\
\text { BCRD x BAFF }\end{array}$ & $.6650^{* * *}$ & $\begin{array}{l}3,9502^{* * *} \\
.2673^{\star * *} \\
.5312^{\star \star *} \\
-.0903^{*}\end{array}$ & $\begin{array}{l}.2614 \\
.0541 \\
.0574 \\
.0388 \\
\end{array}$ & $\begin{array}{l}15.1110 \\
4.407 \\
9.2519 \\
-2.3280 \\
\end{array}$ & $\begin{array}{c}3,4348 / 4,4655 \\
, 1607 /, 3740 \\
, 4180 /, 6443 \\
-, 1668 /, 0138 \\
\end{array}$ \\
\hline $\begin{array}{l}\text { Model } 3 \\
\text { Constant } \\
\text { BCRD } \\
\text { BAFF } \\
\text { BCRD } \times \text { BAFF } \\
\text { Gender } \\
\text { BCRD } \times \text { Gender } \\
\text { BAFF } \times \text { Gender } \\
\text { BCRD } \times \text { BAFF } \times \text { Gender }\end{array}$ & $.6699^{* * *}$ & $\begin{array}{l}4,0013^{\star * *} \\
.2738^{* * *} \\
.5288^{* * *} \\
-.0893^{*} \\
.0659 \\
-.1331 \\
-.0390 \\
.0214\end{array}$ & $\begin{array}{l}.2396 \\
.0548 \\
.0584 \\
.0390 \\
.1202 \\
.1203 \\
.1250 \\
.0902 \\
\end{array}$ & $\begin{array}{l}16.6966 \\
4.9944 \\
9.0486 \\
-2,2884 \\
.5482 \\
-.1 .1067 \\
-.3117 \\
.2366 \\
\end{array}$ & $\begin{array}{c}3,5288 / 4,4737 \\
, 1657 /, 3819 \\
, 4136 /, 6440 \\
-, 1663 /-.0124 \\
-, 1710 /, 3028 \\
-, 3703 /, 1040 \\
-, 2853 /, 2074 \\
-, 1566 /, 1993 \\
\end{array}$ \\
\hline $\begin{array}{l}\text { Model } 4 \\
\text { Constant } \\
\text { BCRD } \\
\text { L. attendance } \\
\text { BCRD x L. attendance } \\
\end{array}$ & $.5358^{* * *}$ & $\begin{array}{l}3.8030^{\star * *} \\
.5201^{* * *} \\
.0491^{* * *} \\
-.0209^{\star} \\
\end{array}$ & $\begin{array}{l}.3161 \\
.0544 \\
.0096 \\
.0086 \\
\end{array}$ & $\begin{array}{l}13.0300 \\
9.5549 \\
5.0903 \\
-2.4353 \\
\end{array}$ & $\begin{array}{c}.3 .1798 / 4.4262 \\
.4128 / .6274 \\
.0301 / .0681 \\
-.0378 /-.0040 \\
\end{array}$ \\
\hline $\begin{array}{l}\text { Model } 5 \\
\text { Constant } \\
\text { CRDB } \\
\text { L. attendance } \\
\text { CRDB } x \text { L. attendance } \\
\text { Gender } \\
\text { CRDB } \times \text { Gender } \\
\text { L. attendance } x \text { Gender } \\
\text { CRDB } x \text { L. attendance } \times \text { Gender }\end{array}$ & $.5811^{\star * *}$ & $\begin{array}{l}4.0852^{* \star *} \\
.5903^{\star * *} \\
.1071^{\star * *} \\
-.1240^{* * *} \\
-.0254 \\
-0762 \\
-.0377 \\
.0730^{* * *}\end{array}$ & $\begin{array}{l}.3104 \\
.1567 \\
.0305 \\
.0265 \\
.1234 \\
.1125 \\
.0237 \\
.0193\end{array}$ & $\begin{array}{l}13.1629 \\
3.7661 \\
3.5104 \\
-4.6787 \\
-.2057 \\
-.6772 \\
-1.5889 \\
3.7881\end{array}$ & $\begin{array}{c}3,4733 / 4,6971 \\
, 2813 /, 8993 \\
, 0469 /, 1672 \\
-, 1762 /-, 0717 \\
-, 2687 /, 2179 \\
-, 2980 /, 1456 \\
-, 0845 /, 0091 \\
, 0350 /, 1110\end{array}$ \\
\hline
\end{tabular}

Note: BCRD: brand credibility; BAFF: brand affect; L. attendance: live attendance; B: unstandardized coefficients; SE: standard error; Cl: bias-corrected 95\% bootstrap confidence intervals; *: $\mathrm{P}<.05 ;{ }^{* * *}: \mathrm{P}<, 001$.

Whether the conditional effects of brand affect on the relationship between brand credibility and behavioural intentions depended on gender was questioned in Model 3 in Table 2. At this stage, gender and all interaction terms comprising all possible pairings of previous predictor variables (i.e., Model 2) with gender were added to the Model 3. All variables affecting the dependent variable were centralized and age and education level were also controlled. All predictor variables included the analysis explained a significant $67 \%$ of the variance in behavioural intentions $(\mathrm{F}=46.45 ; \mathrm{p}<.001)$. However, the 
interaction term of CRDB $x$ BAFF $x$ Gender $(\beta=.02 ; p>.05)$ which is the interest of this step and the changes in $\mathrm{R} 2$ with the addition of the conditional effect of gender $(\mathrm{F}=0.56$; $\mathrm{p}>05$ ) were not significant. Hence, Hypothesis 4 was rejected.

Table 3: Conditional Effects of Brand Credibility at Different Values of Brand Affect

\begin{tabular}{lllllll}
\hline Brand affect & $\mathbf{B}$ & SE & $\mathbf{t}$ & $\mathbf{p}$ & LLCI & ULCI \\
\hline-1.0523 & .3624 & .0702 & 5.1630 & .0000 & .2240 & .5007 \\
.0000 & .2673 & .0541 & 4.9407 & .0000 & .1607 & .3740 \\
+1.0523 & .1723 & .0653 & 2.6386 & .0090 & .0436 & .3010 \\
\hline
\end{tabular}

Note: B: unstandardized coefficients; SE: standard error; LLCI and ULCI: lower level and upper level of the bias-corrected $95 \%$ bootstrap confidence intervals.

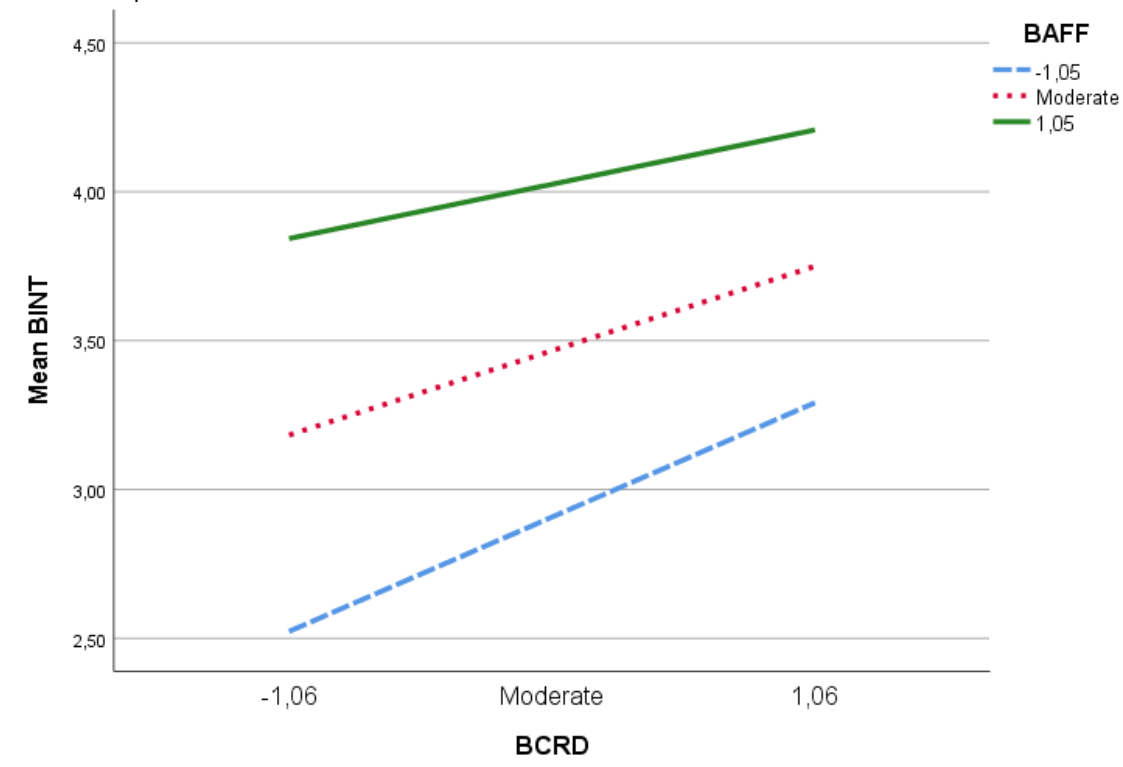

Figure 1: Visual Depiction of the Indirect Effect of Brand Credibility on Behavioural Intentions as a Function of Brand Affect

Note: BINT: behavioural intentions; BCRD: brand credibility; BAFF: brand affect.

Whether the conditional effects of brand affect on the relationship between brand credibility and behavioural intentions depended on gender was questioned in Model 3 in Table 2. At this stage, gender and all interaction terms comprising all possible pairings of previous predictor variables (i.e., Model 2) with gender were added to the Model 3. All variables affecting the dependent variable were centralized and age and education level were also controlled. All predictor variables included the analysis explained a significant $67 \%$ of the variance in behavioural intentions $(\mathrm{F}=46.45 ; \mathrm{p}<.001)$. However, the interaction term of CRDB $\times$ BAFF $\times$ Gender $(\beta=.02 ; p>.05)$ which is the interest of this step and the changes in $\mathrm{R} 2$ with the addition of the conditional effect of gender $(\mathrm{F}=0.56$; $\mathrm{p}>05$ ) were not significant. Hence, Hypothesis 4 was rejected.

In Model 4, the moderator variable live attendance and the interaction term BCRD x L. attendance were added to the first model (i.e., Model 1). All variables affecting the dependent variable were centralized, and gender, age and education level were also control variables. Results were presented under Model 4 in Table 2. All predictor variables included in the analysis explained a significant $54 \%$ of the variance in behavioural 
intentions $(\mathrm{F}=40.20 ; \mathrm{p}<.001)$. The results showed that the interaction term had a negative and significant effect $(\beta=-.02 ; p<.05)$. The significance of the interaction term indicates that live attendance moderates the proposed relationship. The changes in R2 with the addition of the conditional effect of live attendance $(\mathrm{F}=5.93 ; \mathrm{p}<05)$ were also significant. Next, the nature of the relationship between brand credibility and behavioural intentions was examined at different levels of live attendance. The results were given in Table 4 and illustrates in Figure 2. Interaction slopes showed that the effect of brand credibility on behavioural intentions was at $\beta=.62 ; \mathrm{p}<.001$ level when the live attendance is 1 standard deviation below the means, and decreases to $\beta=.52 ; \mathrm{p}<.001$ level at the means level, and decreases to the lowest level $\beta=.39 ; \mathrm{p}<.01$ when it is 1 standard deviation above the means. This demonstrates that the higher the live attendance, the lesser the brand credibility effect on behavioural intentions. Hence, Hypothesis 5 was accepted.

Table 4: Conditional Effects of Brand Credibility at Different Values of Live Attendance

\begin{tabular}{lllllll}
\hline L. attendance & $\mathbf{B}$ & $\mathbf{S E}$ & $\mathbf{t}$ & $\mathbf{p}$ & $\mathbf{L L C l}$ & $\mathrm{ULCl}$ \\
\hline-5.0231 & .6251 & .0713 & 8.7711 & .0000 & .4846 & .7656 \\
.0000 & .5201 & .0544 & 9.5549 & .0000 & .4128 & .6274 \\
+6.1678 & .3912 & .0738 & 5.3010 & .0000 & .2457 & .5367 \\
\hline
\end{tabular}

B: unstandardized coefficients; SE: standard error; LLCI and ULCl: lower level and upper level of the bias-corrected $95 \%$ bootstrap confidence intervals.

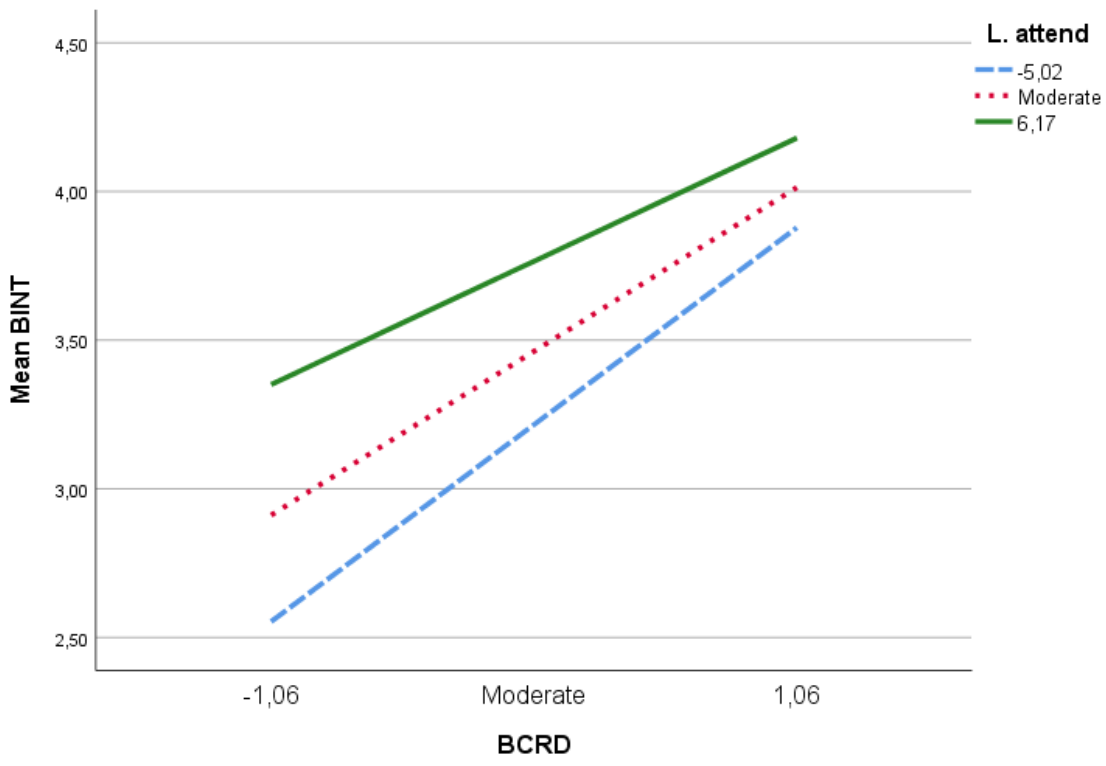

Figure 2. Visual Depiction of the Indirect Effect of Brand Credibility on Behavioural Intentions as a Function of Live Attendance in Stadium

Note: BINT: behavioural intentions; BCRD: brand credibility; L. attend: live attendance.

Upon the result above, whether the conditional effect of live attendance on the relationship between brand credibility and behavioural intentions depended on gender was questioned in Model 5 in Table 2. Gender and all interaction terms comprising all possible pairings of previous predictor variables (i.e., Model 4) with gender were added to the Model 5. Predictors affecting the dependent variable were centralized and age and education level were also controlled. All predictor variables included in the analysis 
explained a significant $58 \%$ of the variance in behavioural intentions $(\mathrm{F}=31.76 ; \mathrm{p}<.001)$. The interaction term of CRDB $x$ L. attendance $x$ Gender $(\beta=.07 ; p>.001)$, and the changes in $\mathrm{R}^{2}$ with the addition of the conditional effect of gender $(\mathrm{F}=14.35 ; \mathrm{p}>.001)$ were significant. Next, the nature of the conditional effect of live attendance on the relationship between brand credibility and behavioural intentions was examined on the conditional effect of gender. The conditional effect of live attendance on the relationship between brand credibility and behavioural intentions was only significant for male consumers. The results were given in Table 5 and illustrated in Figure 3. For male consumers, the effect of brand credibility on behavioural intentions from low live attendance to high live attendance respectively were $\beta=0.77, \mathrm{p}<, 001 ; \beta=0.51 ; \mathrm{p}<.001$ and $\beta=0.20: p<.05$. Hence, Hypothesis 6 was accepted.

Table 5: Moderated Conditional Effect of Live Attendance on the Relationship Between Brand Credibility and Behavioural Intentions by Gender

\begin{tabular}{llllllll}
\hline L. attendance & Gender & $\mathbf{B}$ & SE & $\mathbf{t}$ & $\mathbf{p}$ & LLCl & ULCI \\
\hline-5.0231 & Male & .7700 & .0813 & 9.4742 & .0000 & .6098 & .9302 \\
.0000 & Male & .5141 & .0634 & 2.5874 & .0000 & .3891 & .6392 \\
6.1678 & Male & .1999 & .0919 & 8.1054 & .0307 & .0188 & .3810 \\
\hline
\end{tabular}

B: unstandardized coefficients; SE: standard error; LLCI and ULCI: lower level and upper level of the bias-corrected 95\% bootstrap confidence intervals.

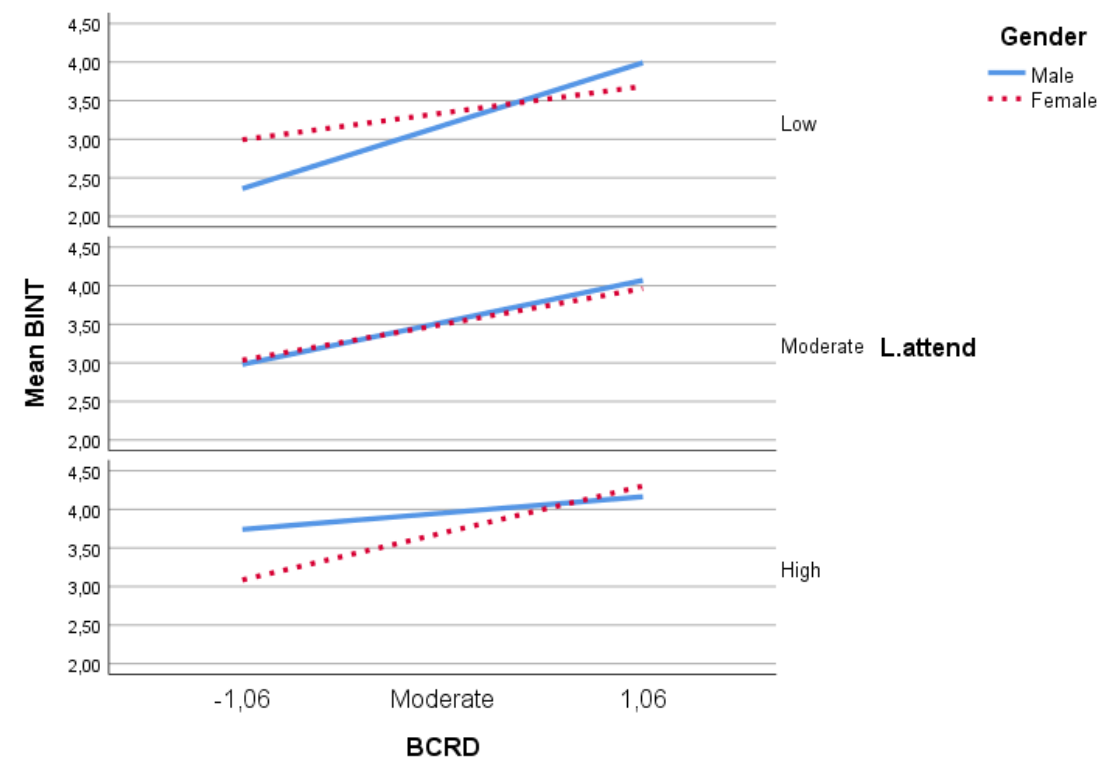

Figure 3: Visual Depiction of the Indirect Effect of Brand Credibility on Behavioural Intentions as a Function of Live Attendance in Stadium by Gender

Note: BINT: behavioural intentions; BCRD: brand credibility; L. attend: live attendance.

\section{Conclusion}

The purpose of this study was to investigate the effect of brand credibility and brand affect on behavioural intentions of sports team consumers toward their teams, and also 
investigating the moderating role of their brand affect level, live attendance frequency in stadium and gender in this relationship. With this study, the brand credibility was empirically tested for the first time in the sports team branding context to understand it is role on behavioural intentions of consumers. The results first contributed to the existing sports brand management literature by revealing the significant and positive direct effect of brand credibility as a cognitive response on behavioural intentions of sports team consumers. In line with Keller's (2001) suggestion, this finding in this study was also clarified the ambiguous result by previous study (Gordon \& James, 2017) showing that cognitive responses did not have a direct effect on consumer behavioural intentions in the context of sports teams. Second, this study also extended and advanced to the body of knowledge in sports team branding literature beyond brand associations brand loyalty relationships through revealing the interaction effect of brand credibility, in the moderation of brand affect, live attendance frequency and gender on behavioural intentions of sports team consumers.

The significant and positive effect of brand credibility on behavioural intentions (H1) confirmed the CBBE pyramid of Keller (2001). This result was also in line with similar outcomes, such as Sweeney and Swait (2008), who demonstrated the effect of brand credibility on loyalty commitment and continuance commitment, and Zayerkabeh et al., (2012) who found the significant and positive direct influence of brand credibility on brand loyalty, and Wang and Yang (2010) who observed the significantly positive direct impact of brand credibility on brand purchase intention. Hence, the more credible the sports team brand, the higher is the behavioural intention toward that brand.

The significant and positive effect of brand affect on behavioural intentions (H2) confirmed the CBBE pyramid of Keller (2001) and Gordon and James (2017) who have found the significant and positive effect of brand affect on the brand resonance of sports team consumers. More importantly, brand affect was revealed to be a buffering moderator on the relationship between brand credibility and behavioural intentions. Interaction slopes showed that from low level to high level of brand affect, the magnitude of the brand credibility on behavioural intentions gradually decreased while remaining positive and significant, which confirmed the H3. However, the conditional effect of brand affect on the relationship between brand credibility and behavioural intentions was not moderated by gender, in another term, it did not vary by gender. Therefore, $\mathrm{H} 4$ was rejected. There was no prior research in sports brand management literature that explored the moderation of brand affect on the relationship between brand credibility and behavioural intentions. This result found in this study is comparable to study of Gordon \& James (2017), in which the crucial effect of brand affect on the relationship between consumer cognitive responses and brand attitudinal and behavioural intentions in the example of brand superiority in the context of sports teams was shown. Our study, however, is different and complementary in that it shows how consumer cognitive responses in the example of brand credibility can affect behavioural intentions under what conditions of brand affect. Thus, it offers different implications.

Live game attendance frequency also moderated the relationship between brand credibility and behavioural intentions. The interaction slopes showed that from low level to high level of live attendance, the magnitude of the brand credibility on behavioural intentions gradually decreased while remaining positive and significant, which confirmed the H5. There was no prior research in sports brand management literature that explored the moderation of live game attendance behaviour of sports team consumers on the relationship between brand credibility and behavioural intentions. Considering that live attendance in the team's matches, in general, is more associated among fans or consumers 
with higher levels of involvement and emotion (Pritchard \& Funk, 2006), it justifies that cognitive responses rather than emotional responses are significant for consumers as the frequency of attendance decreases. Moreover, the moderation effect of live attendance on the relationship between brand credibility and behavioural intentions was significant for male consumers while it did not significant for female consumers. That is the interaction effect varied between gender and confirmed H6. For male consumers, the magnitude of brand credibility on behavioural intentions from low attendance to high attendance gradually decreased while remain positive and significant. The change in magnitude of brand credibility on behavioural intentions as a function of live attendance by gender is attributable to the differences in respect to brand judgements among gender. (Melynk et al., 2009; Shay et al., 2011).

\section{Implications}

The importance sports consumers attached to brand credibility of a team in respect to their behavioural intentions differed at their varying level of brand effect, stadium attendance frequency and gender, however, both brand credibility and brand affect were significantly and positively associated in their behavioural intentions. This knowledge was most valuable insight this paper offers sports marketers. It indicates that sports marketers should take into account the different responses of both consumer segment which can be described as "cognitively-less attendees" and "emotionally-frequent attendees" to the information sources of the brand in the designing and efficiency of marketing programs. In other words, attention should be paid to whether consumers are making decisions in head or heart, as Keller (2001) put it, for guiding behavioural intentions of potential and existing sports consumers toward a team. For example, those who had fewer feelings for a team and exhibited less live attendance in the team's matches (cognitively-less attendees) were more concerned with the credibility of a brand in terms of their behavioural intentions. Hence, actions that emphasize brand credibility of the team should take precedence in promotion efforts for this segment. Conversely, those who had higher feeling and exhibited more attendance in the team's matches (emotionally-frequent attendees) were concerned about what emotion a team gives them rather than it is credibility. Therefore, promotional actions that prioritize the emotions and benefits that the team can give them should be emphasized more in the promotion efforts for this segment. Another issue to be considered for managers is that unlike female consumers, the importance given to brand credibility by male consumers decreased with their live attendance.

Although one of the most important factors that strengthen a sports team brand credibility is trophies it wins, sports marketers can enhance the brand credibility of their teams, at least, by ensuring that the signals they send through each element of the marketing mix are always stable and clear to consumers regarding trustworthiness and expertise. In addition, rather than mostly unpredictable game quality, especially for the teams staying away from success on the pitch, it can be another alternative to take part in social issues in the regional or international community or committed to spreading universal values for enhancing the brand credibility. Manchester United's "allredallequal" campaign which comprises equality, diversity and inclusion is a good example for the latter idea. Publicising the transfer of credible new star players through all communication tools could be an effective strategy to improve the credibility of the team brand.

Since, purchasing a spectator sports product and being loyal to a team is not commercial but mostly emotional, eliciting brand emotion is crucial in favourable behavioural intentions of sports team consumers. Therefore, sports marketers could 
publicize indirect messages about how it feels consuming their team product such as belonging something admirable through all social and traditional media platforms to increase brand affect. Lastly, brand credibility is an essential asset for a team to attract potential consumers and maintain existing consumers with confidence. However, it mostly depends on on-field success for sports teams and is susceptible to damage quickly in any adverse event. Therefore, focusing on increasing emotional attachment between consumers and team brand, which may cause consumers to be less affected by adverse situations that may result from damage to the credibility of the brand in terms of their loyalty, could be a reasonable strategy of sports marketers.

\section{Limitations and Future directions}

There are some limitations and future directions to be noted in this study. Since the convenience sampling method was used and only football (soccer) team consumers involved with the study, the generalizability of the result for other sports settings requires consideration. Perceived risk, consumer involvement or media consumption which may have an impact on the relationship between brand credibility and behavioural intentions and also purchasing intentions as a consumers' other behaviours could be considered in future research.

\section{References}

Aaker, D.A. (1991). Managing brand equity: Capitalizing on the value of a brand name. New York: Free Press.

An, J., Do, D. K. X., Ngo, L. V., \& Quan, T. H. M. (2019). Turning brand credibility into positive word-of-mouth: integrating the signaling and social identity perspectives. Journal of Brand Management, 26(2), 157-175.

Bauer, H. H., Stokburger-Sauer, N. E., \& Exler, S. (2008). Brand image and fan loyalty in professional team sport: A refined model and empirical assessment. Journal of sport Management, 22(2), 205.

Biscaia, R., Correia, A., Ross, S., Rosado, A. F., \& Maroco, J. (2013). Spectator-based brand equity in professional soccer. Sport Marketing Quarterly, Vol. 22 (1), pp. 20-32.

Byrne, B. M. (2001). Structural Equation Modelling with Amos: Basic Concepts, Applications, and Programming. USA, Lawrence Erlbaum Associates, Publishers.

Chaudhuri, A., \& Holbrook, M. B. (2001). The chain of effects from brand trust and brand affect to brand performance: the role of brand loyalty. Journal of marketing, 65(2), 81-93.

Clemes, M. D., Brush, G. J., \& Collins, M. J. (2011). Analysing the professional sport experience: A hierarchical approach. Sport Management Review, 14(4), 370-388.

Cronin, J. J., Brady, M. K., \& Hult, G. T. M. (2000) Assessing the effects of quality, value, and customer satisfaction on consumer behavioral intentions in service environments, Journal of Retailing, 76, $193-218$.

Doyle, J. P., Filo, K., McDonald, H., \& Funk, D. C. (2013). Exploring sport brand double jeopardy: The link between team market share and attitudinal loyalty. Sport Management Review, 16 (3), pp.285-297.

Erdem, T., \& Swait, J. (1998). Brand equity as a signaling phenomenon. Journal of consumer Psychology, 7(2), 131-157. 
Erdem, T., \& Swait, J. (2004). Brand credibility, brand consideration, and choice. Journal of consumer research, 31(1), 191-198.

Erdem, T., Swait, J., \& Louviere, J. (2002). The impact of brand credibility on consumer price sensitivity. International journal of Research in Marketing, 19(1), 1-19.

Filo, K., Funk, D. C., \& Alexandris, K. (2008). Exploring the role of brand trust in the relationship between brand associations and brand loyalty in sport and fitness. International Journal of Sport Management and Marketing, 3 (1-2), pp.39-57.

Fink, J. S., Trail, G. T., \& Anderson, D. F. (2002). Environmental factors associated with spectator attendance and sport consumption behavior: Gender and team differences. Sport Marketing Quarterly, 11(1).

Fornell, C., \& Larcker, D. F. (1981). Evaluating structural equation models with unobservable variables and measurement error. Journal of marketing research, 39-50.

Gladden, J.M., \& Funk, D.C., (2001). Understanding brand loyalty in professional sport: Examining the link between brand associations and brand loyalty, International Journal of Sports Marketing and Sponsorship, 3 (1), 67-94.

Gordon, B. S., \& James, J. D. (2017). The impact of brand equity drivers on consumerbased brand equity in the sport service setting. International Journal of Business Administration, Vol.8 No.3 pp.55-68.

Hair, J. F., Black, W. C., Babin, B. J., \& Anderson, R. E. (2006). Multivariate Data Analysis. USA, Pearson Education.

Hayes, A. F. (2013). Introduction to mediation, moderation, and conditional process analysis. New York, USA: The Guilford Press.

Hayes, A. F., \& Rockwood, N. J. (2017). Regression-based statistical mediation and moderation analysis in clinical research: Observations, recommendations, and implementation. Behaviour research and therapy, 98, 39-57.

Keller, K. L. (1993). Conceptualizing, measuring, and managing customer-based brand equity. Journal of marketing, 57(1), 1-22.

Keller, K. L. (2001). Building customer-based brand equity: A blueprint for creating strong brands (pp. 3-27). Cambridge, MA: Marketing Science Institute.

Kline, R. B. (2005). Principles and practice of structural equation modelling (2.Ed.). N.Y. USA. The Guilford Press.

Kunkel, T., Funk, D., \& King, C. (2014). Developing a Conceptual Understanding of Consumer-based League Brand Associations. Journal of Sport Management, 28(1).

Little, T. D., Card, N. A., Bovaird, J. A., Preacher, K. J., \& Crandall, C. S. (2007). Structural equation modeling of mediation and moderation with contextual factors. Modeling contextual effects in longitudinal studies, 1, 207-230.

Mahony, D. F., Madrigal, R., \& Howard, D. (2000). Using the psychological commitment to team (PCT) scale to segment sport consumers based on loyalty. Sport marketing quarterly, $9(1)$.

Mason, D. S. (1999). What is the sports product and who buys it? The marketing of professional sports leagues. European Journal of Marketing, Vol.33 No3/4 pp.402418.

Matzler, K., Bidmon, S., \& Grabner-Krauter, S. (2006). Individual determinants of brand affect: the role of the personality traits extraversion and openness to experience. Journal of Product and Brand Management, 15(7), 427-434. 
Melnyk, V., Van Osselaer, S. M., \& Bijmolt, T. H. (2009). Are women more loyal customers than men? Gender differences in loyalty to firms and individual service providers. Journal of Marketing, 73(4), 82-96.

Mittal, Banwari. 2006. I, me and mine: How products become consumers' extended selves. Journal of Consumer Behavior 5(6): 550-562.

Mullin, B. J., Hardy, S., Sutton, W. A. (2007). Sport Marketing (3.bs.). Champaign, IL: Human Kinetics.

Nufer, G., \& Rennhak, C. (2006). The nature of sports marketing (No. 2006-06). Reutlinger Diskussionsbeitr\%o ge zu Marketing \& Management.

Nunnally, J. C. (1978), Psychometric Theory (2. ed.), McGraw Hill, New York.

Parasuraman, A., Valarie Zeithaml, and Leonard Berry (1988), "SERVQUAL: A Multiple-Item Scale for Measuring Consumer Perceptions of Service Quality," Journal of Retailing, 64 (Spring), 12-40.

Pritchard, M. P., \& Funk, D. C. (2006). Symbiosis and substitution in spectator sport. Journal of Sport Management, 20(3), 299-321.

Sahay, A., Sharma, N., \& Mehta, K. (2012). Role of affect and cognition in consumer brand relationship: Exploring gender differences. Journal of Indian Business Research.

Sweeney, J., Swait, J. (2008). The effects of brand credibility on customer loyalty. Journal of Retailing and Consumer Services, 15(3), 179-193.

Theodorakis, N. D., \& Alexandris, K. (2008). Can service quality predict spectators' behavioral intentions in professional soccer?. Managing Leisure, 13(3-4), 162178.

Thompson, C.J., Rindfleisch, A., \& Arsel, Z. (2006). Emotional branding and the strategic value of the doppelganger brand image. Journal of Marketing, 70(1), 50-64.

Vincent Couvelaere, \& André Richelieu (2005) Brand Strategy in Professional Sports: The Case of French Soccer Teams, European Sport Management Quartely, 5:1, 23-46.

Wang, X., \& Yang, Z. (2010). The effect of brand credibility on consumers' brand purchase intention in emerging economies: The moderating role of brand awareness and brand image. Journal of Global Marketing, 23(3), 177-188.

Yağız, K. (2020). The role of fan identification on the relationship between sports league brand associations and psychological commitment. European Journal of Physical Education and Sport Science, 6(9).

Zayerkabeh, S., Albabayi, A., \& Abdoli, M. (2012). Studying the effect of brand credibility and brand prestige on brand loyalty. Australian Journal of Basic and Applied Sciences, 6(8), 160-166. 